\title{
Uzaylı Olarak 'Öteki': \\ Yasak Bölge 9 Filminin Post-kolonyal Kavramlar ile Okunması
}

\author{
Ece Vitrinel ${ }^{*}$
}

Özet

Dikkatleri medyanın klişeleri pekiştirici, bilgiyi tektipleştirici gücüne, vurguyu temsil sorununun ve temsillerin üreticisi konumundaki kültür endüstrilerinin üzerine çeken 1978 tarihli Şarkiyatçılık; 1970'li yılların sonundan itibaren edebiyat, kültür incelemeleri ve cinsiyet araştırmalarm da içine alan geniş bir yelpazeyi kapsayacak şekilde gelişen post-kolonyal çalışmalara ilham veren kurucu bir metin olarak kabul edilir. Edward W. Said'in bu eserine dayanarak, Doğu ve Batının coğrafi kavramlar olmaktan ziyade Batının kendi eliyle yarattığı ayrımlara kaçınılmazlık süsü verme becerisini somutlaştıran bir ikilik olduğu söylenegelmiştir. Oryantalist söylemin çıkış noktasının temelde Batının kendi üstünlüğ̈̈nü üzerinden göreceği bir 'öteki' yaratma stratejisi olduğu düşünüldü̈̆̈̈̈nde, dev bir kültür endüstrisi olarak Hollywood Sinemasının sunduğu 'vahşi Siyahlar' ve 'gizemli Doğulular' temsillerinin, farklı toplumsal bağlamlardan kaynaklanan fakat aynı amaca hizmet eden öteki kurguları oldukları iddia edilebilir. Bu çalı̧̧manın amacı da, yönetmeni Neill Blomkamp tarafindan "Güney Afrikalı bir Hollywood filmi" olarak tanımlanan 2009 yapımı District 9 (Yasak Bölge 9) filmi aracılı̆̆ ile ne Doğulu ne de Siyah olan kurmaca karakterler üzerinden 'öteki' söyleminin nasıl kurulduğunu göstermek ve 'istilact uzayln' klişesini ters yüz eden bu filmin, ötekinin ötekisini yaratırken bir noktada eleştirdiği şeye dönüşüp dönüşmediğini tartışmaktır. Bu film okumasında kılavuzumuz 'melezlik' başta olmak üzere post-kolonyal literatürün temel kavramlarn olacaktır.

Anahtar Kelimeler: Ötekilik, temsil politikalan, uzaylı filmleri, melezlik, post-kolonyal film okuması, Yasak Bölge 9

* ORCID ID: https:/ / orcid.org/0000-0002-7048-5280

E-Mail: ecevitrinel@gmail.com

DOI: $10.31122 /$ sinefilozofi.405525

Geliş Tarihi - Received: 14.03.2018

Kabul Tarihi - Accepted: 12.06.2018 


\title{
The 'Other' as an Alien:
}

\section{A Postcolonial Reading of the Movie District 9}

\author{
Ece Vitrinel*
}

\begin{abstract}
Orientalism (1978), which draws attention to the power of the medias in uniformizing information and reinforcing stereotypes, thus to the problem of representation and to the cultural industries, is regarded as a founding text that inspires post-colonial studies covering a wide range of domains including literature, cultural and gender studies. Based on this work of Edward W. Said, rather than being geographical concepts, East and West are thought be a duality which illustrates the ability of the West to create a distinction, and then to present it as inevitable. Assuming that the starting point of the orientalist discourse is a strategy of creating an 'other' by reference to which the supremacy of the West will be assessed, it can be claimed that 'wild Blacks' and 'mysterious Easterners' represented by the gigantic cultural industry Hollywood cinema, are constructions of the 'other' that originate from different social contexts but serve the same purpose. The aim of this article is to understand how the discourse of the other - along with the other's other - is constructed in the movie District 9 (Neill Blomkamp, 2009) through fictional characters which are neither Easterner nor Black. We also want to discuss if this "South African Hollywood film" - as described by its director - inverting some important clichés like 'invader alien' ends up by creating another cliché at one point or not. In this film reading, our guide will be the common notions of post-colonial literature, the 'hybridity' in particular.
\end{abstract}

Keywords: Otherness, politics of representation, alien films, hybridity, post-colonial film reading, District 9

* ORCID ID: $\underline{\text { https:/ / orcid.org/0000-0002-7048-5280 }}$

E-Mail: ecevitrinel@gmail.com

DOI: $10.31122 /$ sinefilozofi. 405525

Received - Geliş Tarihi: 03.14.2018

Accepted - Kabul Tarihi: 12.06.2018 


\section{Giriş}

Homi Bhabha ve Ania Loomba gibi post-kolonyal düşüncenin önde gelen isimleri üzerinde etkili olmuş Martinikli psikiyatr-yazar Frantz Fanon, 1952 yılında yayınlanan ırkçılık ve sömürgecilik konulu ilk kapsamlı incelemesi Siyah Deri, Beyaz Maske'nin başlarında şu tespiti yapar: "Siyah insan, insan değildir" (2009: 2). Siyahsanız size bu dünyada rahat yoktur, sinemada yanınıza oturulmaz, aynı dili konuştuğunuz kişi sizle bir çocukla konuştuğu ses tonuyla konuşur, mesleki başarınız sanki ortada çelişkili bir durum varmışçasına "Zenci doktorun başarısı" olarak sunulur, filmlerde ya yamyamsınızdır ya da daha iyisi hizmetkâr. Peki ya uzaylıysanız? Fanon'un mecazi olarak kullandığı şekilde değil de gerçekten insan olmadığınıza göre bu dünyada işiniz Siyahtan daha zor, bir filmde yeriniz Siyahtan daha mı ikincil olacaktır?

Görsel deneyim dolayımlı temsil konusunun ne kadar geniş, George Méliès'in 1902 tarihli Aya Seyahat'inin akrobatvari Serenitelerinden, Denis Villeneuve'ün 2016 yapımı Geliş'inin - adlarının önerdiği gibi - yedi bacaklı Heptapodlarına, sinemada temsil edilen dünya dışı varlık sayısının¹ ne kadar fazla olduğu hesaba katıldığında bu soruya tek bir cevap verilemeyeceği açıktır. Fakat dünya dışılığı uzayla ilişkilendirmeyen The Abbys (James Cameron, 1989) gibi filmler ve yine Cameron'un Avatar'ının (2009) doğayla uyumlu ve barışçıl ama saldırıya uğradıklarında direnişçi Na'vileri² ya da Steven Spielberg'ün nazik E.T.'si (1982) gibi az sayıda örnek dışında, dünya dışı yaşam formlarının sinemada ağırlıklı olarak istilacı uzaylılar olarak kimlik buldukları gözlemlenebilir. Buradan hareketle, farklılıkları öncelikle ırka özgü nitelikler üzerinden tanımlayan rrkçılıktan ziyade canlılara sadece şu ya da bu türe ait oldukları için farklı değerler atfeden türcülük ve zenofobi kavramlarını konu alan, istilacı uzaylı klişesini, uzaylıları dünyada mülteci ${ }^{3}$ konumunda sunarak tersten okumaya girişen District 9 (Yasak Bölge 9, Neill Blomkamp, 2009) filminin konuya getirdiği bakış açısı incelemeye değerdir. Filmin gösterime girer girmez akademik ilgiye mazhar oluşu da söz konusu bakış açısının sunduğu çeşitli okuma imkânlarının bir göstergesidir. Öncelikle Moses vd. 2010'da yayınlanan bir derlemede filmin dokunduğu ekoloji, kentsel dönüşüm, göç, sömürgecilik, şiddet, militarizm, suç, etnik ayrımcılık, sosyal dışlanma, politik çürümüşlük, çokuluslu yapılanma, yabancılaşma, kimlik, yoksulluk, ucubelik gibi çok sayıda temayı ortaya

\footnotetext{
${ }^{1}$ Wikipedia' nın çeşitli listelerden derlenmiş ve eksiksiz olma iddiasında olmayan dünya dışı varlıkları konu alan filmler listesinde 522 başlık yer almaktadır. https://en.wikipedia.org/wiki/List_of_alien_films\#tite_note-blastr-1 (Erişim: 20 Ekim 2017)

${ }^{2}$ Battle For Terra (Terra'yı Kurtarmak, Aristomenis Tsirbas, 2007) adlı animasyon film, Avatar'dan iki yıl önce Avatar'a çok benzer bir tema etrafında barış̧̧ bir Terra gezegeni ve sakinleri portresi çizmiştir.

3 İnsan Hakları Evrensel Bildirisi'nin 14. Maddesinde geçen sığınma hakkına dayanarak Birleşik Milletler Mülteciler Yüksek Komiserliği (BMMYK) tarafından belirlenen tanıma göre 'mülteci', "1rkı, dini, tabiiyeti, belirli bir sosyal gruba mensubiyeti veya siyasi düşüncesi nedeniyle zulme uğrayacağından korktuğu için vatandaşı olduğu ülkeye dönemeyen veya dönmek istemeyen" kişidir (Madde14.org). Yasak Bölge 9'un uzaylılarının dünyaya ne amaçla geldikleri bilinmese de kendi gezegenlerine dönme imkânlarının bulunmadığı ve yoğun hak ihlallerine maruz kaldıkları bir kamp alanında belli bir hukuki çerçeve içinde barındırıldıkları görülmektedir. Bu durum onları ülkelerini daha iyi koşullar için isteyerek terk etmiş ve arzu ettiklerinde geri dönebilecek 'göçmenler'den ayırmakta, film evreni içinde 'mülteci' ya da 'sı̆̆ınmacı' statüsünde değerlendirilmelerinin kapısını aralamaktadir.
} 
dökmüştür. Ardından da bu temalar ekseninde kaleme alınmış çeşitli makaleler Yasak Bölge 9'u sadece ilk akla gelen Avatar (2009) gibi dünya dışı gezegen ve canlıları konu alan filmler ile değil, Fly (Sinek, David Crononberg, 1986) gibi dönüşüm hikâyeleri; Mad Max (George Miller, 1979-2015), Blade Runner (Bıçak Sırtı, Ridley Scott, 1982) gibi distopyalar ya da Coming Home (Athol Fugard, 2009), Viva Riva! (Djo Tunda Wa Munga, 2010) gibi doğrudan Afrika kitasına uzanan anlatılar ile karşılaştırarak çözümlemeye girişmiştir (Rieder, 2011; Veracini, 2011; Nel, 2012; van Veuren, 2012; Walder, 2014; Frassinelli, 2015 ve Duncan, 2018). Bu film okumasının iskeletini ise 1970'li yllların sonundan itibaren edebiyat, kültür incelemeleri ve cinsiyet araştırmalarını da içine alan geniş bir yelpazeyi kapsayacak şekilde gelişen ve kolonyal geçmiş ve uzantılarının entelektüel üretimdeki baskın rolünü - geçmiş ve sömürgeciliğin tasfiye edildiği toplumlarla sınırlı kalmaksızın - sorgulayan post-kolonyal çalışmalar ve onun, 'melezlik' başta olmak üzere, 'ötekilik', 'aradalık', 'tektipleştirme' gibi temel kavramları oluşturacaktır.

Bir gün (sene 1982'dir) bir uzay gemisi; Independence Day (Kurtuluş Günü, Roland Emmerich, 1996), War of the Worlds (Dünyalar Savaşı, Steven Spielberg, 2005) gibi pek çok Hollywood bilim kurgusundan farklı olarak Washington, New York, Los Angeles, Chicago ya da olay örgüsünün geçtiği ana mekânı etkilemeyen Londra, Paris gibi Avrupa megopolleri - değil de Johannesburg semalarına konuşlanır. Geminin kapılarının kapalı kaldığı ve uzaylılarla hiçbir temasın yaşanmadığı üç ayın sonunda gemiye zorla girilir ve uzun süredir iyi beslenememiş, sağlıksız ve lidersiz çok sayıda uzaylı ile karşılaşılır. Güney Afrika Hükümeti'nin üzerinde büyük bir uluslararası baskı vardır. Gemi yakınında geçici bir kamp kurulur ve etrafı tellerle çevrilen bölge (9. Bölge) kısa sürede büyük bir kenar mahalle halini alır. Artan suç olayları ve şehir halkının uzaylılara karşı ayaklanması sonucunda geminin Johannesburg'a gelişinden 20 yıl sonra Multinational United (MNU), sayıları 1.8 milyona ulaşmıs uzaylıyı 9. Bölge'den çıkarıp 10. Bölge'ye, Johannesburg'a 200 km. uzaklıkta yeni bir kampa taşımaya karar verir. UIO protokolüne göre uzaylıları tahliye etmek için onlara 24 saat süre tanınması gerekmektedir. Uzaylılara tahliye kararının bildirileceği ve I-27 belgesinin imzalatılacağı operasyonun başına aynı zamanda MNU başkanının damadı olan Wikus van der Merwe getirilir. Koobus Venter yönetiminde özel bir askeri tim de Wikus van der Merwe' ye eşlik edecektir.

Yapımcılığını Peter Jackson'un Carolynne Cunningham ile birlikte üstlendiği Yasak Bölge 9, sırtını kurmaca kişi ve olayların belgesel anlatı teknikleri kullanılarak gerçek kişi ve olaylarmış gibi yansıtıldığı mokümanter (mockumentary, sahte belgesel) türüne dayayan bir bilim kurgudur. Jenerik öncesi bölümde filmin ana kahramanı Wikus van der Merwe elindeki yaka mikrofonunu test ederken “Böyle mi bakayım ?" diye sorarak kameraya doğru döner ve görüntüye girmeyen, varlığı derinlerden gelen sesi aracılığı ile hissedilen kameramanın onayıyla seyirciye bakarak konuşmaya başlar. Görevini "MNU ve insanlık için uzaylılarla ilişkilerimizi geliştirmek" olarak tanımladığı Multinational United'a bağlı Uzaylı İlişkileri Departmanı'nı tanıtan Wikus'ı, film boyunca televizyon belgeseli estetiği ve uzman görüşü alma geleneği çerçevesinde röportajlarını izleyeceğimiz UKNR Başkanı Grey Bradnam, sosyolog Sarah Livingston, CIV Heyet Uzmanı François Moran, sosyal yardım uzmanı Dr. Katrine Makenei, uzman mühendis Forest Feldman gibi kişilerin konuşmaları izler. Belgesel 
türünün ve dolayısıyla belgeselmiş gibi davranma prensibi üzerine kurulu mokümanterin de gerektirdiği gibi, hikâye hakkında film karakterlerinden daha az bilgiye sahip olan seyirci, bu konuşmalar aracılığı ile uzaylıların evlerine dönememelerinin sebebinin geminin çalışmaması olduğu gibi önemli detayları öğrenir. Bu durum da, kumanda modülünün gemiden sebebi bilinmeyen bir şekilde bilinmeyen bir yere düşmüş olmasından kaynaklanmaktadır. Geminin şehre gelişi ya da halk ayaklanması gibi olaylar haber bültenlerinden alınmış görüntülerle, uzaylılarla ilk temas ise üzerinde timecode yazılı, kalitesi düşük ve titreyen, dolayısıyla arşiv görüntüsü izlenimi veren aktüel çekimlerle verilir. Wikus van der Merwe'nin operasyonun başına getirildiğinin açılandığı toplantı görüntüleri de benzer bir arşiv mantığ1 aracılığı ile bize yansırken, Wikus'ın gururdan ağlayan annesi, karısı ve aile fotoğrafları aracılığı ile seyircinin filmin öne çıkaracağı ana karakter ile tanışması sağlanır. Filmin ilk saniyelerinden itibaren anlatının gidişatı açıktır: 9. Bölge'nin tahliye operasyonu gerçekleşmiştir, şimdi izleyeceğimiz ise bu operasyonu, yöneticisi başta olmak üzere, gerçekleştirenler ve operasyona tanık olanların ağzından dinleyeceğimiz, halk röportajları ve arşiv görüntüleri ile zenginleştirilmiş bir belgeseldir. Karakterlerin aksine bizim henüz bilmediğimiz ise operasyonun nasıl sonuçlandığıdır ve filmin daha ilk on dakikası içinde araya giren Wikus'ın yardımcısı Fundiswa Mhlanga'nın turuncu hükümlü giysisi ile “Bunu herkesin izlemesini istiyorum. Gerçekten ne olduğunu görsünler" gibi bir nevi ileriye atlama (flashforward) görevi gören açıklamaları, olacaklara ilişkin merakı tetikleyerek izleyiciyi anlatıya davet eder.

\section{Uzaylı Varoşu 9. Bölge}

Felsefi düşüncede ırk ve ırkçllık kavramlarının izini süren Irk Kavramını Kim İcat Etti? isimli derlemesinde, Albert Memni'nin 1950'lerde Sömürgeleştiren ve Sömürgeleştirilen adlı eserinde ele aldığı bir konuyu yeniden dile getiren Robert Bernasconi şöyle der: “ ... sömürgeci ilişkilerin hüküm sürdügüu bir ortama yeni gelen biri, genellikle kendi denetiminin ötesindeki yollarla, kaçınılmaz biçimde ya sömürgeleştirenlerden ya da sömürgeleştirilenlerden biri haline gelmeye doğru çekilir" (1999: 7). Uzaylı istilasına dair pek çok bilim kurguda uzay gemisinin New York ya da Washington'a inmesi nasıl sebepsiz değilse ve Amerika Birleşik Devletleri'nin gücünü ve hükümranlığını, genellikle ailesini kurtararak kahramanlaşan bir beyaz erkek yan anlatısı ile birlikte, tüm dünyayı hedef alan bir tehdit karşısında pekiştirme amacına hizmet ediyorsa (Ryan ve Kellner, 2016: 310), yönetmen Neill Blomkamp' in 2005 tarihli kısa filmi Alive in Joburg'dan uyarladı̆̆ 1 ve senaryosunu Terri Tatchell ile birlikte kaleme aldığı Yasak Bölge 9' da geminin Johannesburg'a, hem de 1982 yılında konuşlanması da tesadüf değildir.

1948-1994 yılları arasında, 1949 yılından itibaren yasalarla da desteklenen Apartheid sisteminin Siyahları ancak Beyaz azınlığın yararlanabildiği pek çok vatandaşlık hakkından mahrum bıraktığı, Fanon'un “2.530.300 Beyazın 13.000.000 Siyahı sopa zoruyla tıktığı bir kazan" (2009: 92) olarak tanımladığı Güney Afrika Cumhuriyeti'nin başkentine gelme gafletinde bulunan niyetleri anlaşılamamış ama güçsüz konumdaki uzaylılar vakit geçmeden sömürgeleştirilenlerin en alt konumunda yerlerini alırlar. Amerikalıların Siyahları linç etmek yerine gettolarda soyutlamaya çalışmalarını "herkes kendi çöplüğüne" mantığı ile açıklayan Fanon, Siyah Afrika'nın Siyah şehirlerinde Avrupalılar için ayrılmış semtlerin olmasına da 
şaşırmadığını söyler (2009: 55). 1950 yılında çıkarılan Group Areas Act (Grup Alanları Kanunu) uyarınca Apartheid yönetimi tüm kentsel alanları 'whites only' (sadece Beyazlar girebilir) olarak kodlamaya başlamış, diğer 'ırk gruplarını' şehir dışına, banliyölere taşınmaya zorlamıştır (Duncan, 2018: 50). Yasak Bölge 9 filmine adını veren, sı̆̆ınmacı-uzaylıların önce yerleştirildiği sonra da çıkarılmaya çalışıldığı 9. Bölge de, Apartheid rejiminin sürdüğü 1966 yılında hükümet tarafından sadece Beyazların girebileceği bir alan olarak tanımlandıktan sonra 60.000'den fazla insanın zorla tahliye edilerek $25 \mathrm{~km}$. uzaktaki Cape Flats'e taşındığ 6. Bölge, Cape Town'a doğrudan bir göndermedir (Johnson, 2009; Duncan, 2018: 60).

Uzaylıların gelişinden sonra Johannesburg şehrinde pek çok mekân kapılarına kırmızı çarpı işaretleriyle "uzaylı giremez" tabelaları asmıştır. Etrafı tellerle çevrili 9. Bölge'de yaşamaya mahkûm uzaylıların gemilerini tamir edip şehirlerinden gitmelerini isteyen halk söz konusu bölge için harcanan paraya kızsa da, bu dünya dışı varlıkların soyutlanarak en azından kendilerinden uzak tutulmalarından memnundur. Çoğunluğu Siyahlarla yapılmış halk röportajlarının hepsi "Gitsinler", "Gitmeliler" ile son bulurken, "Başka bir ülkeden olsalar tamam ama gezegenimizden bile değiller" diyen biri ayrımcılığın esas sebebi olarak türü işaret eder. "Virüs. Çaresi virüs. Uzaylılara bulaştırılması gerek" diyen bir diğeri ise çözümü soykırımda bulacak kadar ileri gider.

Tahliye operasyonunu başlatmak üzere yola çıkan Wikus van der Merwe helikopterde “Karidesler (uzaylılar) başkasına ait topraklar üzerinde olduklarını anlamış değiller. Bu yüzden onlara gidip 'burası bizim toprağımız, lütfen gider misiniz ?' diyeceğiz" açıklamasını yaparak filmin başında "uzaylıların daha güvenli, çok daha rahat ve yaşanılası bir bölgeye transferi" olarak anlattığ 1 tahliyenin altında yatan motivasyonu dile getirmiş olur. Ama saf yapısı nedeniyle MNU başkanı kayınpederi tarafından bir maşa olarak kullanıldığı bu operasyonun gerçek nedeninin seyirci gibi henüz kendisi de farkında değildir.

MNU ekibi Koobus yönetimindeki büyük bir askeri güç eşliğinde 9. Bölge'ye girip baraka baraka gezmeye başladığında biz de mekânı daha yakından tanıma imkânı buluruz. Halkın fazla para harcanıyor diye kızdığı alan derme çatma barakalardan oluşmuş sefalet içinde bir varoştan başka bir şey değildir. Hollywood Sinemasında Oryantalizm adlı kitabında 17. ve 19. yüzyıllar arasında Şark gezileri yapmış Batılı seyyahların metinlerinden hareketle Raiders of the Lost Ark (Kutsal Hazine Avclarl, Steven Spielberg, 1981), The Mummy (Mumya, Stephen Sommers, 1999) ve The Mummy Returns (Mumya'nın Dönüşü, Stephen Sommers, 2001) filmlerinde 'öteki'yi inceleyen Hilal Erkan, bu filmlerde Kahire' nin “...labirenti andıran dar sokakları, pis yaşam alanları ve çıldırmış gibi davranan halkı..." ile “...kargaşa içinde ve esenlikli olmayan..." bir şehir olarak betimlendiğini yazar (2009: 124). Johannesburg'un 'ötekisi' 9. Bölge, ifadesiz, birbirine benzer uzaylıların tuhaf sesler çıkararak çöpler arasında cirit attığı bir alan olarak Batılı gözüyle Kahire ile kıyaslanması dahi zor görünecek kadar pis ve geri kalmış bir biçimde tasvir edilmiştir. Öte yandan uzaylıların temsili, Erkan'ın adı geçen oryantalist Hollywood filmlerinde yerli erkeğin sunumuna ilişkin saptadığı iki temel kalıpla birebir örtüşür. Yasak Bölge 9'un uzaylı ana kahramanı Christopher' un oğlu ile diyalog halinde çöplerde bir şey ararken kadraja girdiği 20. dakikaya kadar söyledikleri anlaşılmayan, Wikus'ın daha sonra 'klik' olarak tanımlayacağı robotik sesler çıkaran anonim uzaylılar ya amaçsızca dolaşan "kayıtsız, umursamaz ve uyuşuk kişiler" (Erkan, 2009: 129) ya da "para için 
her şeyi yapabilecek hain ve açgözlü erkekler" (Erkan, 2009: 128-130) olarak temsil edilmişlerdir. Röportajlardan birinde "Ayağınızdaki ayakkabıyı bile çekip alabiliyorlar" diyen kadının arkasında çöp karıştıran bir uzaylı görülmektedir. Bu temsillerin bilimsel gerekçesi uzman ağzından, entomolojist Clive Henderson'un “Dünyamızda barındırdığımız bu koloni, kesinlikle bir işçi kolonisi. Kendi iradeleri yok, emir alabiliyorlar ve inisiyatif kullanamıyorlar" açıklamasıyla verilir.

9. Bölge'nin tek sakinleri uzaylılar değildir. Filmin 15. dakikasında bebek uzaylıları dövüştürürken kadraja giren Günay Afrikalı Beyaz adamın ötekisi Siyah Nijeryalılar fahiş değerler karşılığında uzaylılara en önemli besin kaynakları kedi mamasını satmaktadırlar. Johannesburg yeraltı dünyasının en güçlü ismi, tahliye sırasında MNU'nun bile çekindiği Obasanjo, Nijeryalıları yönetmekte ve uzaylılardan yiyecek karşılığı ağır silahlar toplamaktadır. Ne var ki Battlestar Galactica (2004) gibi pek çok bilim kurguda olduğu gibi organik yapıl14 bu lazer silahlar yalnızca uzaylı DNA'sı ile birleştiğinde aktif olmakta, insan elinde çalışmamaktadır. Obasanjo topladığı silahları kullanabilme yetisini uzaylı eti yiyerek büyü ile kazanmaya çalışırken dünyanın en büyük silah imalatçısı konumundaki MNU yeraltı laboratuvarlarında uzaylıları paramparça ettiği deneylerle aynı şeyin peşindedir. "MNU'nun uzaylıları tahliye etmek için kullandığı kanunlar tamamen göz boyamaydı. (...) Asıl amaç silahları ele geçirmekti." diyen UKNR Başkanı Grey Bradnam hikâyenin asıl entrikasını işaret eder. Oryantalist Hollywood filmlerinde Batılllarca arzulanan gizemli ve tehlikeli nesne 'kutsal sand1k', 'kayıp hazine' ya da 'bilezik'in (Erkan, 2009: 121-140-189) yerini Yasak Bölge $9^{\prime}$ da ağır lazer silahlar almıştır.

\section{Başka Bir Gezegende 'Karides' ya da Ötekinin Ötekisi Olmak}

Johannesburg semalarına konuşlanan uzay gemisine giren ilk insanlar parlak ışıklar, ilahi bir müzik beklerken karanlık, pis bir ortam ve iyi beslenememiş, sağlıksız çok sayıda eklem bacaklı canlı ile karşılaşırlar. İki bacak üzerinde yürüyebilme, aslında böceksi bir uzaylı tasarlamak arzusundaki yönetmen Neill Blomkamp'ın uzaylıların görsel tasarımını üstlenen Weta Workshop'a verdiği temel ölçüttür. Bu ölçüte "Maalesef insani olmaları gerekiyordu çünkü psikolojimiz suratı ve antropomorfik bir şekli olmayan bir şeyle gerçek bir duygudaşlık kurmamızı engelliyor. Dört bacaklı bir şey görürseniz bunun bir köpek olduğunu düşünürsünüz, böyle programlanmışız" (Oldham, 2009) şeklinde açıklık getirmektedir. Kalabalık, geniş plan uzaylı görüntülerinden sonra bir uzaylıyı tek başına gördüğümüz ilk sahne tuhaf sesler çıkararak çiğ et parçalayan bir uzaylının bel plan görüntüsüdür. İki bacakları üzerinde yürüyebiliyor olsalar da James Hope isimli polisin "Karidese benzemediklerini söyleyemezsiniz. Hepsi koca birer karidese benziyor." demecinde en dolaysız şekliyle dile getirdiği gibi uzaylılara hemen 'karides' adı yakıştırılır. Bu yakıştırma Johannesburg bölgesinde sıklıkla rastlanan ve halk arasında Parktown karidesi olarak bilinen

\footnotetext{
${ }^{4}$ Avatar' 1 Pandora gezegeni sakini Na'vileri de, dost ama egemen oldukları hayvanlarına kuyrukları aracılı̆̆ ile organik olarak bağlanmaktadırlar. Wilhelm ve Mathison, Bir James Cameron Filmi: Avatar. Pandora'nın Biyolojik ve Sosyal Tarihi Hakkında Gizli Rapor adlı kitaplarında bu gibi kavrama yeteneği olan kuyrukları 'prehensil' olarak adlandırmaktadırlar (2010: 188).
} 
bir böcek türüne gönderme yapmaktadır (Duncan, 2018: 58). Fakat filmin sosyologu Sarah Livingston'un belirttiği gibi karides, uzaylıların fiziksel özelliklerini çağrıştırmaktan çok onları 'alt tabakadan', 'çöp yiyenler' olarak yaftalayan bir tabirdir. Böylelikle, 16. yüzyıl İspanyasında, Bartolomé de las Casas'ın karşıtlarının Amerikan Yerlilerine yapılan muameleyi, onların insan olmadıkları gerekçesiyle haklılaştırmaları gibi (Bernasconi, 1999: 34); uzaylıları hayvansılıklarına vurgu yaparak ötekileştiren insanlar da, uzaylı bedeni üzerindeki deney adı altında işkenceye varan her türlü tasarruflarını meşru kılarlar. Peki, yıllar yılı kendileri ötekileştirilmenin en ağırını yaşamış Siyah Nijeryalıların, film anlatısı içinde uzaylıları hiçbir vicdan azabı duymadan uzuvlarını kesip yiyebilecekleri, cinsellik dâhil her açıdan sömürebilecekleri hayvanlar olarak görmeleri nasıl açıklanabilir?

Şarkiyatçılık için yazdığı son sözde "Benim tuttuğum yol, her kültürün gelişimi ile bekasının, farklı, rakip bir alter ego'nun (öteki ben) varlığını gerektirdiğini göstermek oldu. Kimliğin inşası, karşıtların, ötekilerin belirlenmesini gerektirir. (...) Her çă̆, her toplum kendi 'ötekileri'ni yaratır" demiştir Said. 'Başkalık' ve 'başkalığın tanınması' gibi toplumsal bağı üzerinden düşüneceği 'alanlar ötesi' kavramları Freud'dan ödünç alan Enriquez de, Sürüden Devlete'de (1983), insanın kendini, kendi arzusunu yalnızca ötekinin varlığında tanımlayabileceğini ifade etmiştir (2004: 20). Nasıl Beyaz için Siyah bir karşılaştırma unsuru ise (Fanon, 2009: 236), uzaylı ile karşılaşan Siyah için de "biyolojik ölçünme" duygusu gündeme gelir. Lacan'ın 'ayna dönemi' kuramına işaret ederek, “(...) bu mekanizma iyi kavrandığı takdirde, Zencinin Beyaz insandaki 'öteki' imajının yerini tuttuğu ve sonuna kadar da bu yeri koruyacağı anlaşılacaktır" der Fanon (2009: 182). Aynı mekanizma gereği Siyah insan için de Beyaz ötekidir, fakat üzerinden kendini olumlayabileceği bir öteki değil, ekonomik ve tarihsel gerçekler doğrultusunda karşısında boyun eğmeye mahkûm olduğu bir efendi-ötekidir (Fanon, 2009: 182). Bu anlamda Yasak Bölge 9 filminin anlatısı içinde Siyah insanın uzaylıda bulup kucakladığı da kendi varlığını yüceltebileceği bir sömürge-öteki olarak yorumlanabilir.

Aşağı sınıftan insanlarda görülen Zenci nefretini Sartre'ın anti-semit zihniyet için şu söylediklerine dayanarak açıklar Fanon (2009: 91-92): “Zengin zaten ilişkilerini çıkarları doğrultusunda kurmasını bilir. (...) Eğer ben orta-sınıftan biriysem, Yahudi'yi aşağılık ve muzır görmekle hiç olmazsa kendi seçkinliğimi kanıtlamış olurum." Bu sözler Beyaz tarafından ötekileştirilen Siyah Nijeryalı'nın uzaylıyı ötekileştirmede Beyaz insandan neden daha istekli olduğuna da açıklık getirmektedir. Nurcan Pınar Eke'nin yine öteki olgusu üzerinden ama bambaşka bir bağlam ve film özelinde söylediği gibi "Her ötekinin, bir daha ötekisi vardır. Sinema ise bunu göstermekte hem acımasız hem de en etkin bir araçtır" (2016: 122).

Yasak Bölge 9, belli bir güç-güçsüzlük dengesine dayanarak uzaylı imgesi üzerinden ötekileştirilenlerin ötekisini yaratmış ve istilacı uzaylıyı sömürge-uzaylıya dönüştürerek bir Hollywood klişesini de tersten okumuştur. Fakat yönetmeninin deyimiyle "Güney Afrikalı bir Hollywood filmi" (Oldham, 2009) olarak bunu yaparken, Nijeryalı temsilinde yamyamlık, fuhuş ve büyüyü ön plana çıkararak bir başka klişeye imza attığı, yarattığı bu tek boyutlu, tekinsiz hatta canavar imge ile belki de istemeden bir noktada eleştirdiği şeyin kendisine dönüştüğü de iddia edilebilir. Yasak Bölge 9'un tek Nijeryalı 'kötü'sü, - Avatar (2009) filminin 
felçli asker Jake Sully'si gibi - kamuflaj giysileri içinde tekerlekli sandalyeye mahkum çete lideri Obasanjo ${ }^{5}$ değildir. Daha çok Siyahların söz aldığı ve uzaylı düşmanlığının dile getirildiği ilk halk röportajlarından, "Johannesburg yeraltı dünyasının ünlü ismi" olarak tanıtılan Obasanjo'yu ilk görüşümüze; Nijeryalıların bulunduğu bölgeyi zevk için bebek uzaylıları dövüştüren, uzaylı eti yiyen, kedi maması ve kadın ticareti yapan silahlı Nijeryalılar üzerinden tanıyıp Obasanjo ve çevresindekilerin vahşice öldürülmesine tanık olduğumuz ana dek, bir saat elli iki dakikalık film boyunca duygudaşlık uyandırabilecek, insani yönü vurgulanan tek bir Nijeryalı karşımıza çıkmaz. Öyle ki filmin Güney Afrika hükümet yetkililerine yapılan özel gösteriminden sonra İstihbarat Bakanı Dora Akunyili ülkesindeki sinema salonlarından filmin gösteriminin durdurulmasını talep eder ve dağıtımcı Sony'ye resmi bir protesto mektubu gönderir. Bu mektup ile Sony'den sadece özür beklememekte, filmin tüm Nijerya referanslarından arındırılmasını da istemektedir (Vourlias, 2009). Filmi ve yönetmenini ırkçı ve zenofobik olmakla suçlayan bir grup, "District 9 Hates Nigerians" (Yasak Bölge 9 Nijeryalılardan Nefret Ediyor) isimli bir Facebook grubu kurar ve çevrimiçi bir imza metni dolaşıma sokar (Smith, 2009). Bu doğrultudaki ilk eleştirilerden birini bloğunda kaleme alan Nijeryalı-Amerikalı yazar Nnedi Okorafor6 (Duncan, 2018: 67) filmdeki Nijeryalı temsiline o kadar kızar ki, benzer bir uzaylı teması etrafında şekillenen Lagoon (2013) isimli bir roman yazar (Tubosun, 2013). Hotel Rwanda (Terry George, 2004) filmindeki rolü ile taninan Nijerya doğumlu İngiliz aktör Hakeem Kae-Kazim da tartışmada söz alır ve Yasak Bölge 9'un tüm Afrikalıları ilgilendiren negatif stereotipleri güçlendireceğine dair endişelerini dile getirir:

Eğer Afrika kıtasının gerçek anlamda özgürleştirilmesi isteniyorsa, arkamıza yaslanıp, bu 'birkaç çürük elma' betimlemesinin tüm dünyaya yayılmasına izin veremeyiz. (...) Sadece Nijeryahların değil tüm Afrikalıların bu şekilde davrandı̆̆ı fikri tüm dünyaya yayılacak. Bu fikri acı verici buluyorum. Nijeryahların bu şekilde tasvir edilmesinin haklı bir mazereti olamaz (Smith, 2009).

Bu kaygı ve eleştirilerin haklılığını sorgulama noktasında, film anlatısının Nijeryalıları suç olgusu ile ilk nasıl ilişkilendirdiğine bakmak faydalı olabilir. "Kenar mahallenin olduğu yerde suç vardır. 9. Bölge de istisna değildi." Yine filmin sosyologu Sarah Livingston'un ağzından dökülen bu sözler aracılığı ile filmin suçu belli bir kimlik ile değil toplumsal durum ile koşut gördüğü savı öne sürülebilir. Duncan (2018: 47-51), 1994 yılında sonlanan Apartheid rejiminin yerini çokuluslu kapital ve neoliberal düzene bırakması ile birlikte Güney Afrika'daki eşitsizliğin sürmekte olduğunu, üretim ilişkileri bağlamında ırkçılığın, Apartheid döneminden olduğu kadar bu yeni düzenden de beslendiğini belirtmektedir. Zorla dişarıda tutulmuş, yoksullaştırılmış, kenar mahallelerde yaşamaya itilmiş, Apartheid rejiminin ağır mirasını taşıyan topluluklar bu yeni dönemde de açlık ve işsizliğe mahkûm edilmişlerdir. Duncan'a göre (2018: 53) Afrika, Güney Amerika ve Hint alt kitasının gecekondu-

\footnotetext{
${ }^{5}$ Çete liderinin, filmin vizyona girdiği tarihten bir önceki dönemin (1999-2007 arası) Nijerya Başkanı Olusegun Obasanjo ile aynı soyadını taşıdığına dikkat çeken Nijeryalı-Amerikalı yazar Nnedi Okorafor (2009), bu isim benzerliğinin politik bir göndermeden çok tembelliğe, karşılarına çıan ilk Nijeryalı ismine tutunmaya işaret ediyor olabileceğini yazmışırı. Öte yandan Blomkamp'ın yerel referanslara hâkimiyeti - uzaylılara karides yakıştırmasında olduğu gibi - bu ihtimali zayıflatmaktadır.

6 "My response to District 419... I mean District 9", http:/ / nnedi.blogspot.com.tr/2009/08/my-responseto-district-419i-mean.html?q=district+9 (Erişim 21 Şubat 2018)
} 
metropollerinde yaşayan bu topluluklar Davis'in (2006) "artık insanlığını" oluşturmaktadırlar; artık onlar için ne kayıtlı istihdam ne de yalnızca hayatta kalma sürdürülebilir olasılıklardır. Blomkamp'ın film evreninde özel, çokuluslu güvenlik şirketine, küresel silah ticaretine ve kenar mahalle yerleşimine tanıdığı merkeziyet mevcut durumu kavradığını ve böylelikle Yasak Bölge 9'u da bir Apartheid alegorisinin ötesine taşıdığını göstermektedir (Duncan 2018: 57). Duncan'ın bu analizi doğrultusunda Blomkamp'ın suç kavramını da çok daha geniş ve katmanlı bir perspektiften ele aldığı, onu acılı bir tarihe dayanan güncel bir bağlamla ilişkilendirmeye çalıştı̆̆ iddia edilebilir. Filmin ırkçı olduğuna dair tartışmaya filmi savunan bir noktadan katılan bir başka Nijeryalı blog yazarı da fikrini benzer bir suç temelli bakış üzerinden dile getirir:

Ĕ̆er Yasak Bölge 9 Nijeryahlardan gerçekten nefret ediyorsa, açık ki gü̧̈ sahibi beyaz karakterlerinden daha da nefret ediyor. Filmdeki hemen hemen her karakter grubunun kanunları çok az dikkate aldığı veya hiç almadı̆̆ı düşünüldü̈̆̈̈nde Nijeryalılarn ahlaki açıdan iflas etmiş suçlular olarak betimlenmesine karşı çıkmak anlamsız görünüyor. Uzaylilar ülkelerine yollamakla görevli şirket, MNU ve emirleri veren beyaz siyasilerin çoğu eşit derecede cahil, ikiyüzlü ve çürümüş. Askerler zihinleri ele geçirilmiş haydutlar olarak dolaşıyor, şiddet kullanıyor ve şüpheli tahliye emirlerini imzalamak için uzaylılar kandırıyorlar. Bilim insanlar yakalanan 'Karidesler' üzerinde el altından deneyler yapıyor; uzaylılar yasadışı silahlarla donanıp sokaklarda kavga ediyor (Onanuga, 2009).

Gerçekten de filmde toplu uzaylı betimlemelerinden sonra karşımıza çıkan ilk uzaylı görüntüsü et parçalayan bir uzaylıya aittir. Yasak Bölge 9 bize geç tanıştırdığı Christopher ve oğlu dışında duygudaşlık kurabileceğimiz uzaylılar sunmaz7. Yukarıda da bahsettiğimiz gibi diğerleri anonim, kayıtsız hatta zalimdirler. Acımasızlık; doğrudan kanun dışılık, ekonomik çıkar, kısa ya da uzun vadeli rant söz konusu olmadığında da filmin karakterlerinden uzak değildir. 9. Bölge'den uzaylıları tahliye etme operasyonunun başına getirilen başkahraman Wikus van der Merwe, film anlatısı içinde öncelikle saf, iyi niyetli ve sempatik resmedilmiş bir Afrikaner'dir. Fakat bu iyi niyeti, 'tahliye' ya da 'imza' gibi kelimelerin anlamın bile bilmeyen uzaylıları 20 yıldır yaşadıkları evlerinden etme konusunda her hangi bir vicdan azabı duymasına yol açmadığı gibi, tahliye sırasında karşılaştı̆̆ bebekleri besleyen boruları tek tek sökmesini de engellemez. Nüfus kontrol ekibi 40-50 yumurtanın olduğu barınağı yakarken kameraya dönen Wikus neşeli bir şekilde "Yumurtalar

\footnotetext{
7 Tanınmış sinema yazarı Roger Ebert (2009), yönetmen Neill Blomkamp'ın Christopher ve oğluna dış görünüsslerine rağmen sempati duyulabilmesini onlara, diğer uzaylılarda olmayan insani bir vücut dili ve ufaklığa nemli büyük gözler vererek başardığını yazmıştır.

https://www.rogerebert.com/reviews/district-9-2009 (Erişim 25 Şubat 2018)

${ }_{8} \mathrm{Bu}$ baraka sistemi uzaylıların eşeysiz ürediklerine, her bir uzaylının hem erkek hem dişi üreme organlarına ve kendi kendilerini dölleme yeteneğine sahip olduklarına işaret etmektedir. Yumurtalar oluştuğunda ölü inek veya domuz gibi bir besin kaynağına tüpler aracılığı ile bağlanır ve bebek uzaylılar bu şekilde gelişir. Bölge 9'da var olduğu belirtilen türler arası fuhuş, uzaylıların insanlara benzer üreme yapılarına sahip olduklarını ve birbirleriyle de ilişkiye girebildiklerini düşündürmektedir. http://district9.wikia.com/wiki/Non-humans (Erişim 26 Şubat 2018). Wikus'un 'hastalık' olarak tanımlanan dönüşümünün sebebi de medyaya - MNU'nun yönlendirmesi ile uzaylılar ile girdiği cinsel ilişkiler olarak yansır. Filmdeki bu 'virüs kapma' iddiasını Walder (2014) kıtanın HIV/AIDS krizi ile ilişkilendirir.
} 
mısır gibi patlıyor. Küçük uzaylılar mısır patlağına dönüyor" demekten geri durmaz. Böylece, Duncan'ın "hem Apartheid dönemi ayrımcilığının hem de neoliberal yönetici ağzının bir karikatürü" (2018: 56-57) olarak tanımladığı Wikus da suça karışır, soykırımın ortağı olur. Onu ötekinin ötekisi uzaylılara yaklaştıracak duygusal dönüşümün tetikleyicisi aşağıda inceleyeceğimiz fiziksel başkalaşım olacaktır. Öte yandan önce Christopher ve oğlu eşliğinde izleyicinin uzaylıya, ikinci olarak melezleşme sürecinde Wikus'ın uzaylıya, son aşamada da izleyicinin Wikus'a bakışı dönüşürken, film anlatısı Siyah Nijeryalı temsilinde herhangi bir iyileştirme hatta değişime imkân tanımaz. Yine Duncan'ın belirttiği gibi (2018: 69), Beyaz insanın uzaylı nefreti artan işsizlik, kamu kaynaklarının dışarıdan gelen uzaylılar için harcanması gibi sebeplerle açıklanırken, Nijeryalıların canavarca davranışları böyle bir bağlamla ilişkilendirilmiş de değildir.

\section{İnsan-Uzayl1-Makine Melezi Wikus}

Uzaylıların gemisinin kayıp kumanda merkezi aslında bir başka küçük gemidir. 9. Bölge'ye yapılan operasyon sırasında uzaylı Christopher ve küçük oğlu çöplükten topladıkları kendi teknolojilerinden parçalar ile barakalarının altında sakladıkları bu küçük gemiyi harekete geçirecek yakıtı üretme peşindedirler. 20 yıllık uğraşları sonunda toplayabildikleri ile küçük gemiyi ana gemiye götürmeye yetecek kadar yakıtı üretmeyi ancak başarmışlardır ki, baskın sırasında Wikus van der Merwe neye yaradığını bilmediği bu sıvıyı içinde barındıran silindire el koyar. Sıvının vücuduna buluşması sonucunda ise Wikus için dönüşüm başlar.

Wikus van der Merwe'nin yaşadığı Kafkaesk bir dönüşüm değildir. David Crononberg'in 1986 tarihli The Fly (Sinek) filminin kendini ışılanma aracında kalan bir sinek ile beraber ışınlayan ve sineğin moleküler-genetik yapısının kendisininkiyle birleşmesi sonucu başkalaşan bilim insanı karakterinin (Seth Brundle) dönüşümü ${ }^{9}$ gibi ağır ve yer yer acılıdır. Önce tırnakları, sonra dişleri düşer. Bu bağlamda Sinek gibi Yasak Bölge 9 da body horror olarak bilinen ve sosyal, kültürel anlamda insan olma durumunu korkutucu beden deformasyonları, 'doğal olmayan' fiziksel dönüşümler, ucubeleşme üzerinden sorgulayabilen bir alt tür içinde değerlendirilebilir. Wasson ve Alder (2011) bilim kurgu filmlerinde body horror'a sıklıkla teknolojinin karanlık fonksiyonlarına, Frankensteinvari tehditlere işaret etmek için başvurulduğunu söylerler (Aktaran Duncan, 2018: 65). Wikus van der Merwe'nin başkalaşımının da teknolojiye makineleşme üzerinden uzanan bir yanı vardır. Eli uzaylı eline dönüştüğünde yalnızca uzaylıların kullanabildiği lazer silahları çalıştırabilecek hale geldiğinden vücudu doktorun tanımıyla "milyon hatta belki milyarlarca dolar değerinde bir

\footnotetext{
${ }^{9}$ David Crononberg'in 1958 tarihli aynı adlı kült yapımdan uyarladığı Sinek konu aldığı türcülük, dönüşüm ve biyolojik melezleşme dişında da Yasak Bölge 9 filmi ile benzerlikler taşır. Işınlama üzerine çalışan başkahraman Seth Brundle'ın evinde çalışmalara tanıklık eden ve sonra Seth'in kız arkadaşı olan gazeteci deneyleri kameraya almaya ve Seth ile çalışmalarının ilerleyişi, yaşadığı sorunlar hakkında röportajlar yapmaya başlar. Daha sonra Seth'in gazetecinin yokluğunda da kamerayı kullanması ve dönüşümün ardından zaman zaman kendini kayda alması ile film içinde filmin, belgeleyen kameranın ve dolayısıyla belgesel anlatının varlı̆̆ı, Yasak Bölge 9'a olduğu gibi Sinek filmine de ikinci bir katman olarak damgasını vurur. Jake Sully'nin tuttuğu video kayıtlar da Avatar filmine benzer bir katman eklemektedir.
} 
biyoteknoloji"yi de temsil etmeye başlar. Wikus giyilebilir silahları üzerine geçirdiğinde bir insan-makine, özellikle Paul Verhoeven' in 1987 tarihli RoboCop'unun başarısından sonra bilim kurgu filmlerinde görmeye alıştığımız bir tür siborg olur.

RoboCop'un yanı sira The Terminator (Terminatör, James Cameron, 1984), Judge Dredd (Danny Cannon, 1995), Blade Runner (Bıçak Sırtı, Ridley Scott, 1982) gibi örneklerden yola çıkan Carrasco (2006: 103); erkek siborg bedenin erkekliğe dair eski temsil kalıplarını sorgulamaya açmaktansa bu bilindik kalıpları takip ettiğini öne sürer. Oysa "Belki de, alaycı bir şekilde, hayvanlar ve makinelerle füzyonumuzdan, Batıll logosun tecessüm etmiş hali anlamında 'Erkek' olmamayı öğrenebiliriz" diyen Donna Haraway (1991: 310), 1984 yılında kaleme aldığ1 Bir Siborg Manifestosu'nda siborg bedene farklı imkânlar atfetmiştir. "Sibernetik bir organizma, bir makine ve organizma melezi, kurgusal olduğu kadar sosyal gerçekliğe de dair bir varlık" (1991: 291) olarak tanımladığı siborgu, sadece toplumsal cinsiyete değil, birbirine karşıtlık üzerinden tanımlanan ırk, cinsellik ve sınıf gibi tüm kimliklere karşı bir mit olarak sunmuştur. Haraway'a göre siborg Batının yarattığı ikilikler, gücünü bu suni ikiliklerden alan ötekileştirme ve özcülük karşısında konumlanabilir. Bu bakış açısının temelinde siborgun ve/veya melezin iki farklı moleküler yapının birleşiminden öte bir şey, daha önce var olmamış bir yapı olduğu düşüncesinin yattığı iddia edilebilir. Sinek (1986) filminin başkahramanı Seth Brundle da biyolojik melezleşme sürecinde "85 kiloluk bir sinek"ten farklı bir şeye dönüştüğünü söyler ve kendine Brundle Sineği adını verir. Fakat başkalaşımının ileri aşamalarında "insan olduğunu düşlemiş ve bunu sevmiş bir böcek" olduğunu söyler. Dönüşüm öncesinde uzaylı üreme barakasında kayıtsızca besleme borularını söken Wikus'a benzer biçimde Seth'in de hikâyenin başlarında, ışınlama çalışmaları sırasında bir babunu paramparça etmekte beis görmediğine şahit oluruz. Daha sonra bir başka babuna "Kardeşini öldürmek istemezdim", "Kendim yapamayacağım bir şeyi senden istemezdim" gibi sözler sarf ettiğini duysak da Wikus van der Merwe gibi Seth Brundle da türcüdür ve yaşadığ1 dönüşüm şiddet potansiyelini arttırırken türcülüğü ile yüzleşmesine vesile olmaz. Artık kendini de bir böcek olarak tanımlamasına rağmen zalim olduklarını dile getirdiği böceklere güvenemeyeceğimizi söyler. Ona yardım etmek isteyen kız arkadaşından “Kalırsan canını yakacağım" diyerek gitmesini ister. Oysa Seth gibi Wikus'a da tüm ürkütücülüğgune rağmen güç de getiren dönüşüm, Seth'in aksine Wikus'ta Haraway'ın siborg mitinin önerdiği özcülük karşıtlığına uygun bir yol izler.

MNU, DNA'sı için Wikus van der Merwe'nin peşine düşmüştür. Uzaylılar üzerinde

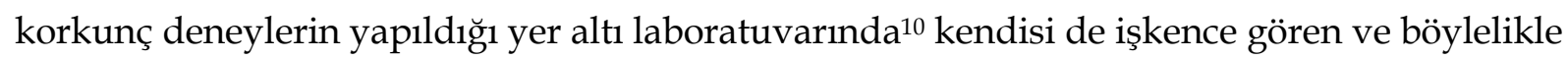
gerçekleri öğrenen Wikus uzaylı Christopher'ın barakasına sığınır. Bu noktada mokümanteri bir kenara bırakarak olayları seyirciye başkahraman Wikus ile birlikte yaşatmaya başlayan anlatı, Wikus gibi bizim de Christopher ve oğluna ısınmamızı sağlayacak bir baba-oğul ilişkisi sunmaya girişir. Aslında başlangıçta, kendini iyileştirebilecek (tekrar insana döndürecek) tekniğin ana gemide mevcut olduğunu öğrendiği için pragmatik sebeplerle Christopher'a yaklaşır Wikus. Dönüşüm geçirmiş kolunu kendisininki ile kıyaslayarak “Aynıyız !” diyen

\footnotetext{
${ }^{10} \mathrm{Nel}$ (2012: 563) filmdeki bu gizli laboratuvar ve orada uzaylılara yapılanların, Apartheid döneminde paramiliter güçlerin konuşlandığı Vlakplaas çiftliğine ve burada hükümet karşıtlarına uygulanan işkencelere doğrudan bir gönderme olduğunu söyler.
} 
küçük uzaylıya sinirlenir. Wikus'ın başına gelenler Avatar (2009) filminde, Na'vi görünümündeki avatarıyla Pandora gezegeninde özgürce koşabilen felçli asker Jake Sully'nin yaşadığının tam tersidir. Sully'nin dönüşümü "gerçeğe dönüşmüş bir rüya" iken Wikus'un dönüşümü "kabusa dönüşmüş bir gerçekliktir" (Veracini, 2011: 357). Özgürlüğü elinden alınmıştır, insan içine çıkamaz, bu dünyanın dışındadır artık. Tuhaflığı ve kategori dışılığı ile kuirdir. Bu noktada Wikus'ın durumunu açıklamak için Nel (2012: 549), Kristeva'nın 'iğrenç' kavramına başvurmayı önerir. Bedeni ikiliklere dayanan semiyotik bir sistem olarak adlandıran Kristeva'nın tanımına göre dışarısı 'iğrenç'tir. İ̆renç; kendi olmayandır, Özneben'in karşıtıdır, dolayısıyla ötekidir, muğlak ve karışmış olan, sınırlara, konumlara ve kurallara saygı göstermeyen, toplumu tehdit edendir (2004: 14-17-23-100). Yaşadığ1 dönüşüm, uzaylılaşan kolu Wikus van der Merwe için önce iğrençtir. Wikus kumanda modülünü harekete geçirecek yakıtı MNU'dan geri alabilmek için Christopher ve oğlu ile birlikte bir maceraya atılır ve laboratuvarda hep birlikte paramparça edilmiş çok sayıda uzaylı ile karşılaştıkları an hikâyenin kırılma noktasını oluşturur. Bu manzaranın önünde nedamet getiren Wikus, MNU'nun emelleri karşısında Christopher ve seyirci ile birlikte bilinçlenerek, sonuçta çok sevdiği karısını bir daha görememe, iyileşememe ya da iyileşmek için yıllarca bekleme pahasına Christopher ve oğlunun evlerine, gezegenlerine dönmesini sağlayacak duygudaşlığa erişir. Avatar' in felçli Beyaz insan bedeninden, sevdiği Na'vi uğruna vazgeçerek geri dönülemez bir biçimde Na'vi olmayı seçen Sully'sinden farklı olarak Wikus van der Merwe; film anlatısının kendi kurduğu ötekine dair ayrımcı söylemi eleştirmesini sağlayan melez bir figüre dönüşmüştür.

\section{Sonuç}

Gelecekle ilgili filmlerin çağdaş toplumsal sorunlara duyarlılığı en düşük film türü olduğu düşünülebilir. Oysa bunlar sık sık Hollywood gerçekliği için fazla radikal sayılacak duruşlarla nitelenirler. Çă̆daş dünyanın en uzağında yer aldığı varsayılan bir tür, bazı bakımlardan, bu dünyanın işleyişini doğrulukla temsil etmek için en elverişli zemini oluşturur. Geleceğe dönük fanteziler, içinde bulunulan anı tırnak içine almanın bir yolu olarak değerlendirilebilir. Bu filmler zamansal yer değiştirmeye başvurarak Hollywood'da egemen olan realist anlatı rejiminin gizli yasaklarm deler (Ryan ve Kellner, 2016: 358).

Bu çalışmaya konu olan Yasak Bölge 9'da uzay gemisinin Johannesburg'a iniş tarihi Apartheid rejiminin sürmekte olduğu 1982 yılıdır. Dolayısıyla ele aldığımız bu film gelecekle ilgili olmayan bir bilim kurgu, zamansız olmayan bir distopyadır. Yine de tam da yukarıda alıntılanan Ryan ve Kellner'in önermelerine uygun bir biçimde, fakat geleceğe değil de geçmişe dönük bir fantezi aracılığı ile bugünü anlatmanın, ayrımcılık ve mültecilik sorununu tırnak içine almanın yolunu bulmuştur, senaristler Blomkamp ve Tatchell. İncelememiz bu yolda iki unsurun öne çıtı̆̆ına işaret etmektedir. İlk olarak; mokümanter seçimi kurgu ile gerçekliği, "bu filmde anlatılanlar gerçek olaylardan esinlenmiştir" gibi dışsal metinlere ihtiyaç duymayan doğal bir düzlemde birleştirmiş, fantezi gerçeğe dinamizm katarak yaşanmış ve yaşanmakta olanların altını çizmenin aracına dönüşmüştür. Bu anlamda bu fantastik kurmaca, Baudrillard'ın gerçekten daha gerçek simülakları gibi, adeta belgeselden daha belgeseldir. 
Yasak Bölge 9'un eleştirel söylemini kurmakta ikinci ve asıl dayanağı ise alışageldik kahraman özelliklerine haiz olmayan, anti-kahraman olmak için de fazla saf ve iyi resmedilmiş başkahramanıdır. Yetmişli yılların sonlarından itibaren karşımıza çıkmaya başlayan, temel özellikleri Ryan ve Kellner tarafından "savaşçılık, girişimcilik ve ataerkillik" (2016: 310-311) olarak tanımlanan bireyci Hollywood kahramanlarına benzemez Wikus van der Merwe. Yine Ryan ve Kellner'in tipolojilerine göre düşünecek olursak (2016: 362), o ne tek başına hareket eden bir detektif, ne de - Avatar' ın yukarıda adı geçen Jake Sully'si gibi - cemaati reddeden bir kovboydur. Tıpkı filmin anlatı yapısı gibi kahramanı da gücünü melezliğinden alır. Fakat bu melezlik de; Bakhtinci çokseslilik, küreselleşme ile koşut giden çokkültürlülük ya da postkolonyal teorinin özellikle de Homi Bhabha öncülüğünde ortaya attığ1 ve dilsel düzlemde karşılığını bulan kültürel melezlik gibi kavramlarla11 açıklanamaz. Filmde duygusal ve kültürel dönüşümün anahtarı biyolojik ve fiziksel başkalaşım olmuştur. Yasak Bölge 9, melezliği dilsel değil görsel, kültürelden ziyade fiziksel boyutuyla temsil ederek kavramı biyolojik kökenine geri döndürmüş, böylelikle de onu özcülük, türcülük, rrkçılık karşıtı işlevsel bir figüre dönüştürmüştür. Bunu yaparken ihmal ettiği diğer ötekiler ve resmettiği tek boyutlu Nijeryalı portresinin filmin eleştirel gücünü zayıflatan yumuşak karnını oluşturduğu söylenebilir. Fakat klişelerle kışkırtıcı biçimde oynamaktan geri durmayan Yasak Bölge 9'un Apartheid rejimini olduğu kadar yeni dünya düzenini de kavrayışı, her türlü insan ve dünya dışı varlık grubunu 'iyi' temsil etmekteki gönülsüzlüğü bu iddianın gücünü bir ölçüde zayıflatmaktadır. Nijeryalı gazeteci Tola Onanuga'nın (2009) sinema yazarı Peter Bradshaw' dan aktardığı gibi belki de "film izleyiciye, cevabını vermekle ilgilenmediği soruları sordurmak konusunda cesaret vermektedir." İnsanın geçmişte, bugün ve gelecekte, insan olarak tanımlanan bedeninin ötesinde ne olduğu ve ne olabileceği sorusu da bunların başında gelmektedir.

\footnotetext{
${ }^{11}$ Aijaz Ahmad, Arif Dirlik gibi post-kolonyal düşünceye eleştirel yaklaşan kuramcılar melezliği içi boş ve soyut bir kavram olmakla itham etmiş; kavramın genelleyici, indirgemeci ve hatta özcülük-karşıtı görünürken özcü yaklaşımlarca araçsallaştırılabilme potansiyeline dikkat çekmişlerdir. Benzer biçimde ve daha genel çerçevede post-kolonyal düşüncenin post-kolonyalizme dönüşebilmesi ile ilgili bu yazının amaç ve kapsamını aşan tartışmalar için bkz. Toplumbilim: Postkolonyal Düşünce Özel Sayısı. Sayı: 25, Ekim 2010. İstanbul: Bağlam Yayıncılık.
} 


\section{Kaynakça}

Bernasconi, R. (2007). Irk Kavramını Kim İcat Etti? (Z. Direk, Çev.). İstanbul: Metis.

Calder, J. ve Calder, K. (Yapımcı) \& Tsirbas, A. (Yönetmen). (2007). Terra'yı Kurtarmak (Battle for Terra) [Sinema Filmi]. ABD: Menithings Productions, Snoot Entertainment.

Cameron, J. (Yapımc1) \& Cameron, J. (Yönetmen). (2009). Avatar [Sinema Filmi]. ABD: Twentieth Century Fox.

Carrasco, R. C. (2006). New Heroes on Screen: Prototypes of Masculinity in Contemporary Science Fiction Cinema. Huelva: Universidad de Huelva Publications.

Cornfeld, S. (Yapımc1) \& Cronenberg, D. (Yönetmen). (1986). Sinek (The Fly) [Sinema Filmi]. ABD: Twentieth Century Fox.

Daniel, S. (Yapımc1) \& Sommers, S. (Yönetmen). (2001). Mumya'nın Dönüşü (The Mummy Returns) [Sinema Filmi]. ABD: Universal Pictures.

Daniel, S. (Yapımc1) \& Sommers, S. (Yönetmen). (1999). Mumya (The Mummy) [Sinema Filmi]. ABD: Universal Pictures.

Deeley, M. (Yapımcı) \& Scott, R. (Yönetmen). (1982). Bıçak Sırtı (Blade Runner) [Sinema Filmi]. ABD: The Ladd Company, Warner Bros.

Devlin, D. (Yapımc1) \& Emmerich, R. (Yönetmen). (1996). Kurtuluş Günü (Independence Day) [Sinema Filmi]. ABD: Twentieth Century Fox.

District 9 Wiki. Erişim 26 Şubat 2018, http://district9.wikia.com/wiki/Non-humans

Duncan, R. (2018). From Cheap Labour to Surplus Humanity. World-ecology and the postapartheid speculative in Neill Blomkamp's District 9. Science Fiction Film and Television, 11.1., 45-72.

Ebert, R. (12 Ağustos 2009). District 9. Rogerebert.com. Erişim 25 Şubat 2018, https://www.rogerebert.com/reviews/district-9-2009

Eke, N. P. (2016). Beyazperdede 'Öteki' Olmak. 'Dönersen Islık Çal' Filmi Üzerine Bir İnceleme. SineFilozofi, Cilt 1, Sayı 2, 97-124.

Enriquez, E. (2004). Sürüden Devlete: Toplumsal Bă̆ Üzerine Psikanalitik Deneme. (N. Tutal, Çev.). İstanbul: Ayrıntı Yayınları.

Erkan, H. (2009). Hollywood Sinemasında Oryantalizm. İstanbul: Kırmızı Kedi Yayınevi.

Fanon, F. (2009). Siyah Deri, Beyaz Maske. (C. Koytak, Çev.). İstanbul: Versus.

Frassinelli, P. P. (2015). Heading South: Theory, Viva Riva! and District 9. Critical Arts, 29:3, 293-309. 
Fugard, A. (Yazan). (2009). Coming Home [Tiyatro Oyunu]. New York: Dramatists Play Service.

George, T. (Yapımc1) \& George, T. (Yönetmen). (2004). Hotel Rwanda [Sinema Filmi]. Birleşik Krallık: United Artists.

Haraway, D. (1991). A Cyborg Manifesto. Science, technology and socialist-feminism in the late twentieth century. Simians, Cyborgs and Women: The Reinvention of Nature içinde (291324). New York: Routledge.

Hurd, G. A. (Yapımc1) \& Cameron, J. (Yönetmen). (1989). The Abbys [Sinema Filmi]. ABD: Twentieth Century Fox.

Hurd, G. A. (Yapımc1) \& Cameron, J. (Yönetmen). (1984). Terminatör (The Terminator) [Sinema Filmi]. ABD: Hemdale, Pacific Western.

Jackson, P. ve Cunningham, C. (Yapımcı) \& Blomkamp, N. (Yönetmen). (2009). Yasak Bölge 9 (District 9) [Sinema Filmi]. Güney Afrika, ABD, Yeni Zelanda, Kanada: TriStar Pictures, Sony Pictures.

Johnson, S. C. (26 Ağustos 2009). The Real District 9: Cape Town's District Six. Newsweek. Erişim 22 Ekim 2017, http://www.newsweek.com/real-district-9-cape-towns-district$\underline{\text { six-78939 }}$

Kennedy, B. (Yapımc1) \& Miller, G. (Yönetmen). (1979-1981-1985-2015). Mad Max (seri) [Sinema Filmi]. ABD: Warner Bros.

Kennedy, K. (Yapımcı) \& Spielberg, S. (Yönetmen). (2005). Dünyalar Savaşı (War of the Worlds) [Sinema Filmi]. ABD: Paramount Pictures, DreamWorks.

Kennedy, K. ve Spielberg, S. (Yapımc1) \& Spielberg, S. (Yönetmen). (1982). E.T. (E.T. the ExtraTerrestrial) [Sinema Filmi]. ABD: Universal Pictures.

Kristeva, J. (2004). Korkunun Güçleri: İğrençlik Üzerine Deneme. (N. Tutal, Çev.). İstanbul: Ayrıntı Yayınları.

Levine, D., vd. (Yapımcı) \& Villeneuve, D. (Yönetmen). (2016). Geliş (Arrival) [Sinema Filmi]. ABD: Paramount Pictures.

Lippincott, C. ve Marks B. (Yapımc1) \& Cannon, D. (Yönetmen). (1995). Judge Dredd [Sinema Filmi]. ABD: Hollywood Pictures, Cibergi Pictures Entertainment.

Madde14.org, İltica ve Göç Bilgi Bankası. Erişim 24 Ekim 2017, http://www.madde14.org/index.php?title=M\%C3\%BClteci

Marshall, F. (Yapımcı) \& Spielberg, S. (Yönetmen). (1981). Kutsal Hazine Avcıları (Raiders of the Lost Ark) [Sinema Filmi]. ABD: Paramount Pictures.

Méliès, G. (Yapımc1) \& Méliès, G. (Yönetmen). (1902). Aya Seyahat (Le voyage dans la lune) [Sinema Filmi]. Fransa: Star-Film. 
Moore, R. D., vd. (Yapımc1). (2004-2009). Battlestar Galactica [Televizyon Dizisi]. ABD: British Sky Broadcasting (BSkyB), David Eick Productions, NBC Universal Television.

Moses, M. V., Graham L. V., Marx, J., Gaylard, G., Goodman, R. ve Helgesson, S. (2010). District 9: A Roundtable, Safundi: The Journal of South African and American Studies, 11:1-2, 155175.

Nel, A. (2012). The repugnant appeal of the abject: Cityscape and cinematic corporality in District 9. Critical Arts, 26:4, 547-569.

Okorafor, N. (23 Ağustos 2009). My response to District 419... I mean District 9. Nnedi's Wahala Zone Blog. Erişim 21 Şubat 2018, http://nnedi.blogspot.com.tr/2009/08/my-responseto-district-419i-mean.html?q=district +9

Oldham, S. (14 Ağustos 2009). Interview: Neill Blomkamp. Variety. Erişim 14 Ekim 2017, http://variety.com/2009/film/news/interview-neill-blomkamp-1118007279/

Onanuga, T. (8 Eylül 2009). Why District 9 isn't racist against Nigerians. The Guardian. Erişim 24 Şubat 2018, https://www.theguardian.com/film/filmblog/2009/sep/08/district-9$\underline{\text { racism }}$

Rieder, J. (2011). Race and Revenge Fantasies in Avatar, District 9 and Inglourious Basterds. Science Fiction Film and Television, 4.1, 41-56.

Ryan, M. ve Kellner, D. (2016). Politik Kamera. Çă̆daş Hollywood Sinemasının İdeolojisi ve Politikası. (E. Özsayar, Çev.). İstanbul: Ayrıntı Yayınları.

Said, E. W. (2008). Şarkiyatçılık. (B. Ülner, Çev.). İstanbul: Metis.

Schmidt, A. (Yapımc1) \& Verhoeven, P. (Yönetmen). (1987). RoboCop [Sinema Filmi]. ABD: Orion Pictures.

Smith, D. (2 Eylül 2009). District 9 labelled xenophobic by Nigerians. The Guardian. Erişim: 21 Şubat 2018, https://www.theguardian.com/film/2009/sep/02/district-9-labelledxenophobic-nigerians

Tubosun, K. (7 Mayıs 2013). Nigeria: When aliens took Lagos. The Guardian Africa Network. Erişim 21 Şubat 2018, https:/ / www.theguardian.com/world/2013/may/07/nigeriannedi-okorafor-book

Van Veuren, M. J. (2012). Tooth and Nail: Anxious Bodies in Neill Blomkamp's District 9. Critical Arts, 26:4, 570-586.

Veracini, L. (2011). District 9 and Avatar: Science Fiction and Settler Colonialism. Journal of Intercultural Studies, 32:4, 355-367.

Vourlias, C. (26 Eylül 2009). Nigerians offended by 'District 9'. Variety. Erişim 24 Şubat 2018, http://variety.com/2009/film/features/nigerians-offended-by-district-9-1118009226/

Wa Munga, D. T. (Yapımcı) \& Wa Munga, D. T. (Yönetmen). (2010). Viva Riva! [Sinema Filmi]. Kongo Cumhuriyeti, Fransa, Belçika: Beta Cinema. 
Walder, D. (2014). Hysterical nostalgia in the postcolony: From Coming Home to District 9. Consumption Markets $\mathcal{E}$ Culture, 17:2, 143-157.

Wilhelm, M. ve Mathison, D. (2010). Bir James Cameron Filmi Avatar. Pandora'nın Biyolojik ve Sosyal Tarihi Üzerine Gizli Rapor. İstanbul: Doğan Kitap. 